\title{
Insulin-like Growth Factor II-mediated Proliferation of Human Neuroblastoma
}

\author{
Osama M. El-Badry, " Lee J. Helman, * Jane Chatten, Seth M. Steinberg, ‘ Audrey E. Evans," and Mark A. Israel* \\ *Molecular Genetics Section, Pediatric Branch, ${ }^{\ddagger}$ Biostatistics and Data Management Section, Clinical Oncology Program, \\ National Cancer Institute, National Institutes of Health, Bethesda MD 20892; and \$Pathology Department \\ and "Pediatrics Department, Children's Hospital of Philadelphia, Philadelphia, Pennsylvania 19104
}

\begin{abstract}
Neuroblastoma is an embryonal tumor that typically arises in cells of the developing adrenal medulla. IGF-II mRNA is expressed at high levels in the adrenal cortex before birth but it is not detectable until after birth in the adrenal medulla. Neuroblastoma cell lines corresponding to early adrenal medullary precursors did not express IGF-II, although all three cell lines we tested were growth stimulated by IGF-II. Cell lines corresponding to more mature adrenal medullary cells expressed IGF-II, and one, SK-N-AS, grows by an IGF-II autocrine mechanism (J. Clin. Invest. 84:829-839) El-Badry, Romanus, Helman, Cooper, Rechler, and Israel. 1989. An examination of human neuroblastoma tumor tissues for IGF-II gene expression using in situ hybridization histochemistry revealed that IGF-II is expressed by tumor cells in only 5 of 21 neuroblastomas, but is detectable in cells of nonmalignant tissues including adrenal cortical cells, stromal fibroblasts, and eosinophils in all 21 tumors. These findings indicate that IGF-II may function as an autocrine growth factor for some neuroblastomas and as a paracrine growth factor for others. They suggest that the growth regulatory pathways utilized by neuroblastoma mimic those used in the precursor cell type from which individual tumors arise. (J. Clin. Invest. 1991. 87:648-657.) Key words: paracrine $\bullet$ autocrine $\bullet$ adrenal $\bullet$ development $\bullet$ eosinophil
\end{abstract}

\section{Introduction}

Insulin-like growth factor II (IGF-II) ${ }^{1}$ and IGF-I are chemically similar peptides that share sequence homology with insulin (1). Although distinct cell surface receptors have been identified for IGF-I and IGF-II, both peptides are thought to stimulate growth by binding to the type I IGF receptor (2-5). IGF-I mediates the growth promoting effects of growth hormone during postnatal growth $(6,7)$. In contrast, IGF-II is thought to be involved in fetal growth and development: IGF-II mRNA is

Address correspondence and reprint requests to Dr. Osama El-Badry, Surgery Branch, Building 10, Room 2B42, National Cancer Institute, National Institutes of Health, 9000 Rockville Pike, Bethesda, MD 20892.

Dr. Israel's present address is University of California at San Francisco, Brain Tumor Research Center, Health Science East 722, San Francisco, CA 94143.

Received for publication 22 May 1990 and in revised form 20 September 1990.

1. Abbreviations used in this paper: IGF-I, II, insulin-like growth factor I, II.

The Journal of Clinical Investigation, Inc.

Volume 87, February 1991, 648-657 detected at higher levels in rat and human fetal tissues than in the corresponding adult tissues (8-10); IGF-II has growth promoting effects on fetal cells in vitro $(11,12)$; and fetal tissues display type I IGF receptors on their cell surface (13-15). Expression of high levels of IGF-II mRNA in a number of human embryonal and adult tumors relative to the levels observed in the corresponding tissues of adults $(10,16-19)$ has raised the possibility that IGF-II might contribute to the neoplastic proliferation of tumor cells that express high levels of IGF-II.

Neuroblastoma is a highly malignant tumor of infants and young children (median age at presentation $2 \mathrm{y}$ ) that accounts for up to $50 \%$ of all malignancies among infants (20). Neuroblastomas arise in cells of neural crest origin destined to become chromaffin tissue or neurons of the peripheral nervous system (21). We previously found that IGF-II can mediate the autocrine growth of SK-N-AS neuroblastoma cells (22). Although our studies using Northern blot analysis indicated that IGF-II mRNA was expressed in only a minority of neuroblastomas, all of these tumors expressed the gene encoding the type I IGF receptor (22). We therefore undertook studies to examine further the role of IGF-II in the proliferation of these tumors.

\section{Methods}

Cell lines and cell culture. Human neuroblastoma cells (Table I; see reference 23 for origins of cell lines) were cultured in RPMI 1640 medium containing 10\% FBS (Biofluids, Rockville, MD), penicillin (50 $\mathrm{U} / \mathrm{ml})$, streptomycin $(50 \mu \mathrm{g} / \mathrm{ml})$ and L-glutamine $(2 \mathrm{mM})$, and were incubated at $37^{\circ} \mathrm{C}$ in a humidified incubator containing $5 \% \mathrm{CO}_{2}$. SK$\mathrm{N}$-AS cells were cultured in serum-free N2E medium and incubated in $6 \% \mathrm{CO}_{2}(22)$.

Cell multiplication assays. In preparation for growth assays, SK-N$\mathrm{BE}(2), \mathrm{SK}-\mathrm{N}-\mathrm{DZ}$, and LA-N-1 cells were removed from serum by a step-wise transfer from medium containing $10 \%$ FBS to medium containing 5\% FBS and then $1 \%$ FBS (one passage at each concentration, 7 d each). This medium was twice replaced with serum-free N2E medium containing insulin $(1 \mu \mathrm{g} / \mathrm{ml})$ (Sigma Chemical Co., St. Louis, MO). The first replacement was at 72 , and the second at $24 \mathrm{~h}$ before the initiation of growth assays. SK-N-AS cells were continuously cultured in N2E medium without serum or growth factors (22). On the day of the experiment, cells were dissociated using Puck's saline containing 1 mM EDTA, pelleted, and resuspended in serum-free N2E medium. The cells were subsequently plated at $10^{4}$ /well into 96 -well tissue culture dishes (Costar Data Packaging Corp., Cambridge, MA) in $100 \mu \mathrm{l}$ of serum-free N2E medium with or without IGF-II (Recombinant, human; Bachem Inc., Torrance, CA) and evaluated for growth over a period of $9 \mathrm{~d} .50 \mu \mathrm{l}$ of the culture medium was removed on day 6 and was replaced with $50 \mu \mathrm{l}$ of fresh N2E medium with or without IGF-II. Cell proliferation was examined by the 3-(4,5-dimethylthiazol-2-yl)2,5-diphenyltetrazolium bromide (MTT) assay as previously described (22). Cell number was determined from standard curves relating absorbance to cell number, where $R^{2}$ was $0.998,0.999,0.999$, and 1.000 for SK-N-AS, SK-N-BE(2), LA-N-1, and SK-N-DZ cells, respectively (data not shown). Microscopic examination of treated and untreated cultures confirmed the quantitative assessment of cell number. 
Tissues and tumor samples. 21 neuroblastoma tumor tissues from the primary site were obtained before treatment from 21 children aged newborn to 12 y (4 stage II, 2 stage III, 9 stage IV, and 6 stage IVS) (Evans staging system; 20) at the Children's Hospital of Philadelphia, Philadelphia, PA. Normal fetal adrenal tissues were provided by Dr. T. H. Shepard, Central Laboratory for Human Embryology, Seattle, WA. Normal newborn and adult adrenal gland tissues were obtained from Dr. R. P. Bolande, East Carolina University School of Medicine, Greenville, NC. Tissues used for in situ hybridization histochemistry were fixed in $10 \%$ formalin and paraffin embedded according to standard techniques. Tissues from which RNA was prepared were flash frozen and stored in liquid nitrogen.

Northern blot and in situ hybridization analysis. Total cellular RNA (24) was examined by Northern blot analysis using a ${ }^{32}$ P-labeled plasmid DNA probe containing a cDNA insert encoding rat IGF-II (pr-IGF-II-1, 780-bp insert in pUC12) $(8,22)$ that was labeled to a specific activity of $2-4 \times 10^{8} \mathrm{cpm} / \mu \mathrm{g}$ DNA. Neuroblastoma and normal human adrenal gland tissues (6- $\mu \mathrm{M}$ sections) were processed and examined by in situ hybridization (25) using $5 \times 10^{5} \mathrm{cpm}$ of a 31 -bp synthetic DNA sequence specific for IGF-II (corresponding to nucleotides 535 to $565[22,26])$ that was end labeled to a specific activity of 4 $\times 10^{8} \mathrm{cpm} / \mu \mathrm{g}$ of DNA using $\left.{ }^{35} \mathrm{~S}\right] \mathrm{dATP}$. The exposure time was $5 \mathrm{~d}$.

\section{Results}

IGF-II stimulates the proliferation of human neuroblastoma cells in vitro. In preliminary studies we found that 21 of 26 neuroblastoma cell lines grew well in serum-free N2E medium containing supraphysiological concentrations of insulin $(5 \mu \mathrm{g} /$ $\mathrm{ml}$ ), although most stopped growing after insulin was withdrawn or the concentration was decreased (unpublished observations). Physiological concentrations of IGF-I or IGF-II stimulated the growth of all human neuroblastoma cell lines $(8$ of 8 and 6 of 6 , respectively) tested, while a panel of other peptides including epidermal growth factor, acidic and basic fibroblast growth factors, endothelial cell growth factor, platelet-derived growth factor, transforming growth factor beta 1, or granulocyte macrophage colony stimulating factor did not $(22$; and data not shown). The mitogenic effect of physiological concentrations of IGFs or supraphysiological concentrations of insulin is mediated through the type I IGF receptor $(4,5,22,27$, 28 ), a receptor which is detectable in RNA from all neuroblastoma cell lines ( 8 of 8 ) and tumors ( 8 of 8 ) we have examined, as well as in RNA from adrenal medulla, the tissue from which most neuroblastomas are thought to arise $(22$; and data not shown). We further pursued the role of IGF-II in the growth of neuroblastoma tumors for the following reasons: $(a)$ neuroblastoma is an embryonal tumor and IGF-II is expressed at high levels in the human fetus whereas IGF-I is not (29); (b) IGF-II mRNA had been detected in 3 of 12 neuroblastomas previously examined $(10,22,30,31)$; and $(c)$ the growth of one human neuroblastoma cell line, SK-N-AS, is mediated by endogenously produced IGF-II (22). In contrast, IGF-I is not expressed in poly A+ selected mRNA from neuroblastoma cell lines, and is not detectable in culture medium conditioned by human neuroblastoma cells (22; and data not shown). Also, IGF-II expression has been documented in a large number of different embryonal tumors (e.g., 16-19) whereas IGF-I has not.

The experiment shown in Fig. 1 compares the growth of four human neuroblastoma cell lines after plating at low density in N2E medium supplemented with varying concentrations of IGF-II. SK-N-AS cells, which secrete large amounts of

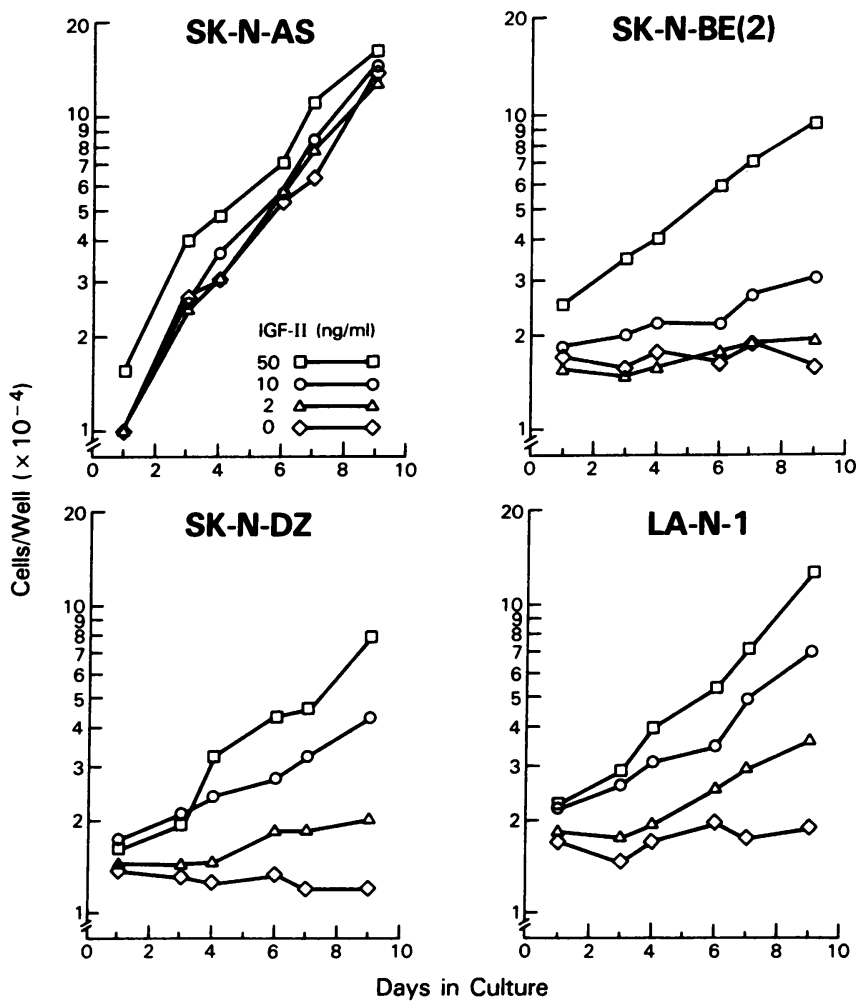

Figure 1. IGF-II stimulates the proliferation of human neuroblastoma cells in vitro. Human neuroblastoma cells were plated at low density into 96-well tissue culture dishes containing N2E medium with or without IGF-II. Cell number was determined on the indicated days using the MTT assay as described in Methods. The data presented are from a representative experiment $(n=2)$ in which each point is the mean of quadruplicate determinations.

IGF-II (22), grew in mitogen-free medium at a rate that was indistinguishable from cells grown in medium containing IGFII (Fig. 1). In marked contrast, three other neuroblastoma cell lines did not grow without added mitogens (Fig. 1, diamonds). The growth of each of these cell lines was stimulated, however, in a dose-dependent manner by IGF-II. The maximum stimulation, six to sevenfold, was observed using IGF-II at $50 \mathrm{ng} / \mathrm{ml}$ (Fig. 1, squares; and data not shown). IGF-II at $20 \mathrm{ng} / \mathrm{ml}$ also stimulated the growth of CHP-382 and SK-N-LE neuroblastoma cells (data not shown).

IGF-II MRNA is detectable in a minority of neuroblastoma cell lines. An examination of IGF-II mRNA expression in total cellular RNA using Northern blot analysis indicated that the 6.1-, 4.6-, and 2.2-kb IGF-II transcripts were detectable in 6 of 22 human neuroblastoma cell lines (Fig. 2, Table I). Among the cell lines that expressed IGF-II, two, SK-N-AS (Fig. 2, lanes 1 and 10 ), and SMS-KAN (Fig. 2, lane 9), expressed high levels of the gene, while others including SK-N-BE(2), NGP, CHP234 (Fig. 2, lanes 5, 7, and 8, respectively), and SK-N-FI (data not shown) expressed much less IGF-II mRNA.

Other work from our laboratory has suggested that neuroblastoma cell lines correspond to cells that occur at different stages in the maturation of adrenal medullary chromaffin cells (23). We therefore correlated IGF-II gene expression in neuroblastoma cell lines (Fig. 2, Table I) with their degree of chromaffin cell maturation (23). As illustrated in Table I, IGF-II 


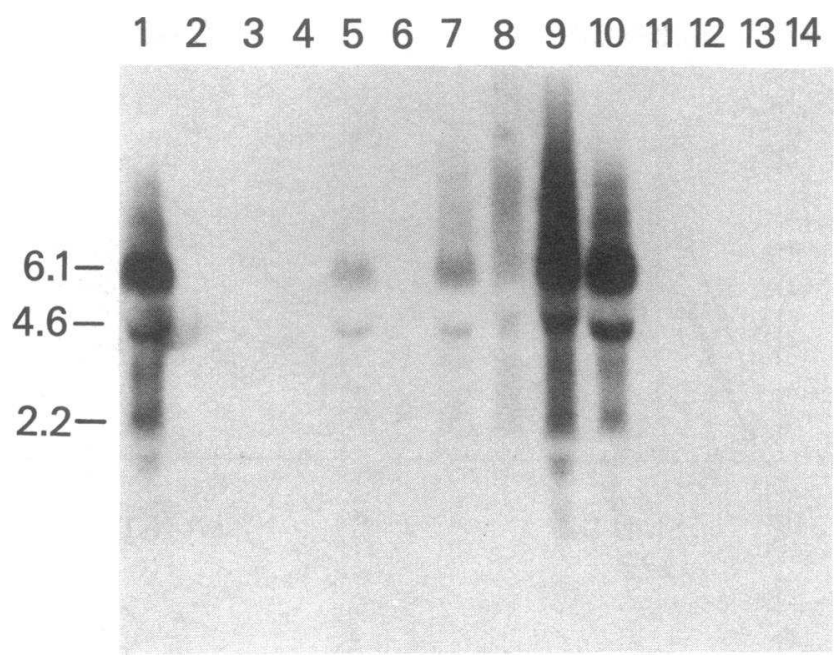

Figure 2. Expression of IGF-II in human neuroblastoma cell lines. Neuroblastoma cell line RNA ( $20 \mu \mathrm{g} / \mathrm{lane})$ was examined by Northern blot analysis. Before the extraction of RNA, human neuroblastoma cells were grown in tissue culture medium containing $10 \%$ FBS with the following exceptions: SK-N-AS was grown in mitogen-free N2E medium (lane 10 ) or N2E medium containing insulin $(1 \mu \mathrm{g} / \mathrm{ml}$, lane 1$)$; SK-N-BE(2) cells were grown in N2E medium containing insulin $(1 \mu \mathrm{g} / \mathrm{ml})$. Lane 1 , SK-N-AS; lane 2 , CHP-404; lane 3, CHP-382; lane 4, NMB; lane 5, SK-N-BE(2); lane 6, SMS-KANR; lane 7, NGP; lane 8, CHP-234; lane 9, SMS-KAN; lane 10, SK-N-AS; lane 11, LA-N-1; lane 12, SK-N-DZ; lane 13, SMS-KCNR; and lane 14, SK-N-LE. Transcript sizes were estimated by comparison of their migration to that observed for $28 \mathrm{~S}$ and $18 \mathrm{~S}$ ribosomal RNAs.

gene expression in neuroblastoma cell lines was detected only in cell lines that we previously determined to express markers of mature adrenal medullary cells (23).

IGF-II mRNA is expressed by malignant cells of some neuroblastomas and by nonmalignant cells of all these tumors. To determine which cells of neuroblastoma tumor tissue express IGF-II, we examined IGF-II gene expression in 21 neuroblastoma specimens using in situ hybridization histochemistry $(26$; see Methods). We detected IGF-II gene expression in tumor cells of 5 of the 21 neuroblastomas evaluated (Fig. 3; and data not shown). IGF-II was expressed at $\sim 10$ times the background level in one tumor (Fig. 3, $A-D$ ) and at 3-5 times background in the other 4 tumors (Fig. 3, $E$ and $F$; and data not shown). Interestingly, the frequency of malignant cells expressing IGF-II was low $(\sim 20 \%$ of the tumor cells in the entire tissue) in the one specimen expressing high levels of IGF-II in tumor cells, while a greater proportion of these cells, 50-75\%, expressed IGF-II in tumors where IGF-II expression was lower (data not shown).

We also detected IGF-II gene expression in several nonmalignant tissues adjacent to tumor cells in all 21 neuroblastomas examined (Figs. 4 and 5). These tissues included adrenal cortical cells (Fig. 4, $A$ and $B$ ). IGF-II expression in such cells was observed in 4 of the 7 neuroblastomas that contained adrenal cortical tissue. IGF-II expression was also detected in neuroblastoma tumor stroma (Fig. 4, $C-F$ ) and capsular tissue (Fig. 4, $E$ and $F$ ) composed primarily of fibroblasts (Fig. $4, C-F$ ). IGF-II expression in stroma was observed in 9 of the 20 specimens that contained stromal tissue. Expression of IGF-II in capsular tis-
Table I. Expression of IGF-II in Human Neuroblastoma Cell Lines

\begin{tabular}{lcc}
\hline \multicolumn{1}{c}{ Cell line } & IGF-II mRNA expression* & Maturity \\
\hline NLF & - & \\
CHP-382 & - & \\
GI-CA-N & - & \\
CHP-404 & - & \\
CHP-134B & - & I \\
GOTO & - & \\
NGP-2 & - & \\
NMB & - & \\
SMS-KCN & - & \\
SMS-KCNR & - & \\
SK-N-DZ & - & \\
IMR-32 & - & \\
SMS-KANR & - & \\
LA-N-1 & - & \\
LA-N-5 & - & III \\
NGP & + & \\
SK-N-BE(2) & + \\
SK-N-LE & - & \\
SMS-KAN & + \\
CHP-234 & + & \\
SK-N-FI & + & \\
SK-N-AS & & \\
\hline & &
\end{tabular}

* +: IGF-II expression detectable in total cellular RNA. -: IGF-II expression not detectable in total cellular RNA.

${ }^{\ddagger}$ I, II, III: relative maturity with III being the most mature (23).

sue was observed in 8 of the 17 specimens that contained capsule.

In all of the 21 neuroblastomas examined, we detected hybridization of our IGF-II probe to eosinophils (Fig. 5). These cells were observed within sheets of tumor cells (data not shown) and in nonmalignant tissues associated with neuroblastomas including hemorrhagic (Fig. 5, $C$ and $D$ ), stromal (Fig. 5, $E-G$ ), and vascular tissues (data not shown). We also detected such cells in a lymph node (Fig. 5, $A$ and $B$ ) and pancreatic tissue (data not shown) associated with metastatic neuroblastomas. We observed marked differences in both the number of eosinophils and the grain counts over eosinophils in the different tumors analyzed (Fig. 5; and data not shown).

IGF-II is expressed at high levels in human fetal adrenal cortical cells. Because of the potential importance of arrested differentiation in the pathogenesis of neuroblastoma (21) we examined normal fetal, childhood, and adult adrenal gland tissues for the expression of IGF-II. Fig. $6(A$ and $B)$ illustrates IGF-II expression in adrenal gland tissues from a 7-8 wk gestation embryo. The hybridization signal was highest in fetal adrenal cortical cells but was also detectable in the neocortex. At 9-10 wk of gestation IGF-II expression was still detectable at low levels in the neocortex but had declined dramatically in fetal adrenal cortex relative to the levels observed at 7-8 wk of gestation (Fig. 6, $C$ and $D$ ). By 20 wk gestation (Fig. 6, $E$ and $F$ ) IGF-II expression was detected with increasing intensity in the neocortex and at approximately the same level in fetal adrenal cortical cells as was observed at 9-10 wk of gestation. In contrast to the high levels of IGF-II expressed in adrenal cortical 

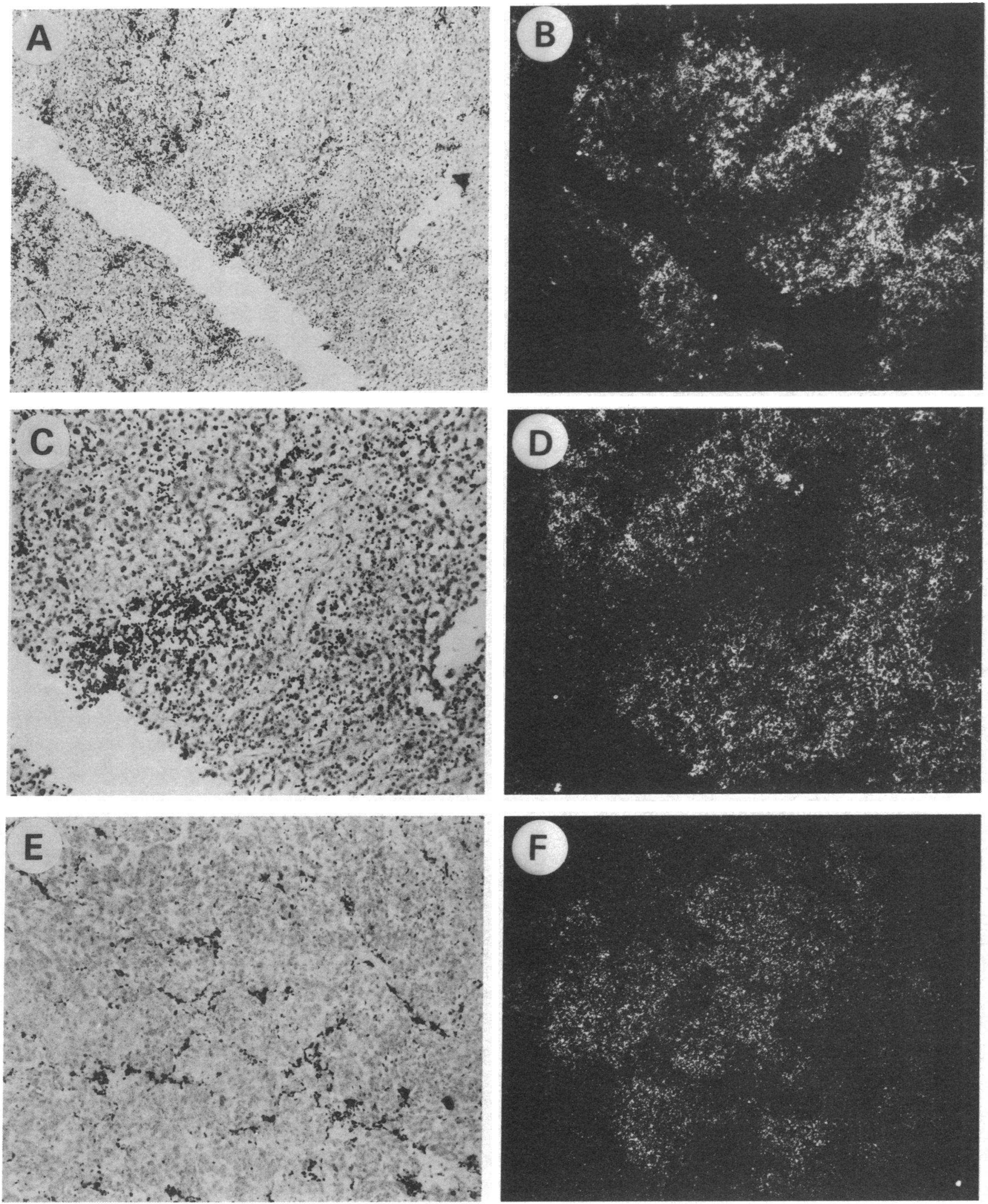

Figure 3. Expression of IGF-II in situ in human neuroblastoma tumor cells. $B, D$, and $F$ are dark field images (silver grains appear as bright spots) of the same views shown in $A, C$, and $E$ using bright field optics (silver grains appear as dark spots). Tissues shown in $A$ and $B$ are magnified, 62 , and are from a 12-yr-old male patient with stage IV neuroblastoma. Using Northern blot analysis, we have previously demonstrated IGF-II gene expression in total cellular RNA extracted from this tumor (22). $C$ and $D$ demonstrate a higher power magnification (125) of the same tissue shown in $A$ and $B$. Samples in $E$ and $F$ are magnified, 250, and are from an adrenal primary of a 1 -yr-old male patient with stage II neuroblastoma. Both patients died of disease. 

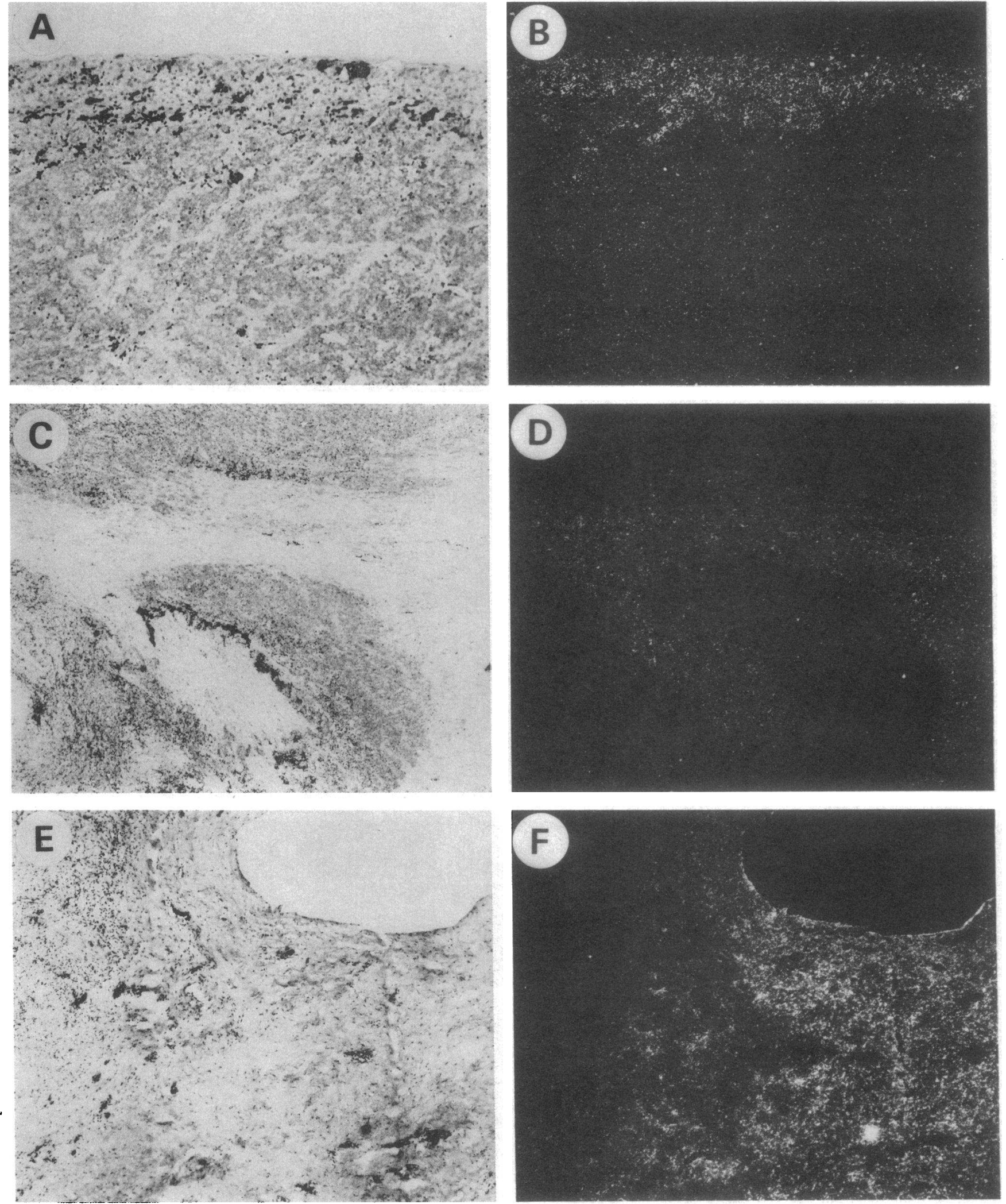

Figure 4. Expression of IGF-II in nonmalignant tissues associated with neuroblastoma tumors. $B, D$, and $F$ are dark field images of the same views shown in panels $A, C$, and $E$. $A$ and $B$ (magnification, 125) demonstrate IGF-II gene expression in adrenal cortical cells surrounding an IGF-II negative neuroblastoma. $C$ and $D$ demonstrate IGF-II gene expression in stromal tissues of an IGF-II negative neuroblastoma (magnification, 62). $E$ and $F$ demonstrate IGF-II gene expression in stromal and capsular tissues surrounding IGF-II negative neuroblastoma tumor cells, which are visible at the upper left of the figure (magnification, 62). Tissues shown in $A$ and $B$ are from a newborn female patient with stage IVS adrenal neuroblastoma. This patient is alive with no evidence of disease more than $5 \mathrm{yr}$ after diagnosis. Tissues shown in $C$ and $D$ are from a 2-wk-old female patient with stage IVS neuroblastoma. This patient died after 47 mo with metastatic neuroblastoma. Tissues shown in $E$ and $F$ are from a 10-mo-old female patient with a stage II thoracic neuroblastoma. This patient is alive with no evidence of disease more than $5 \mathrm{yr}$ after diagnosis. 

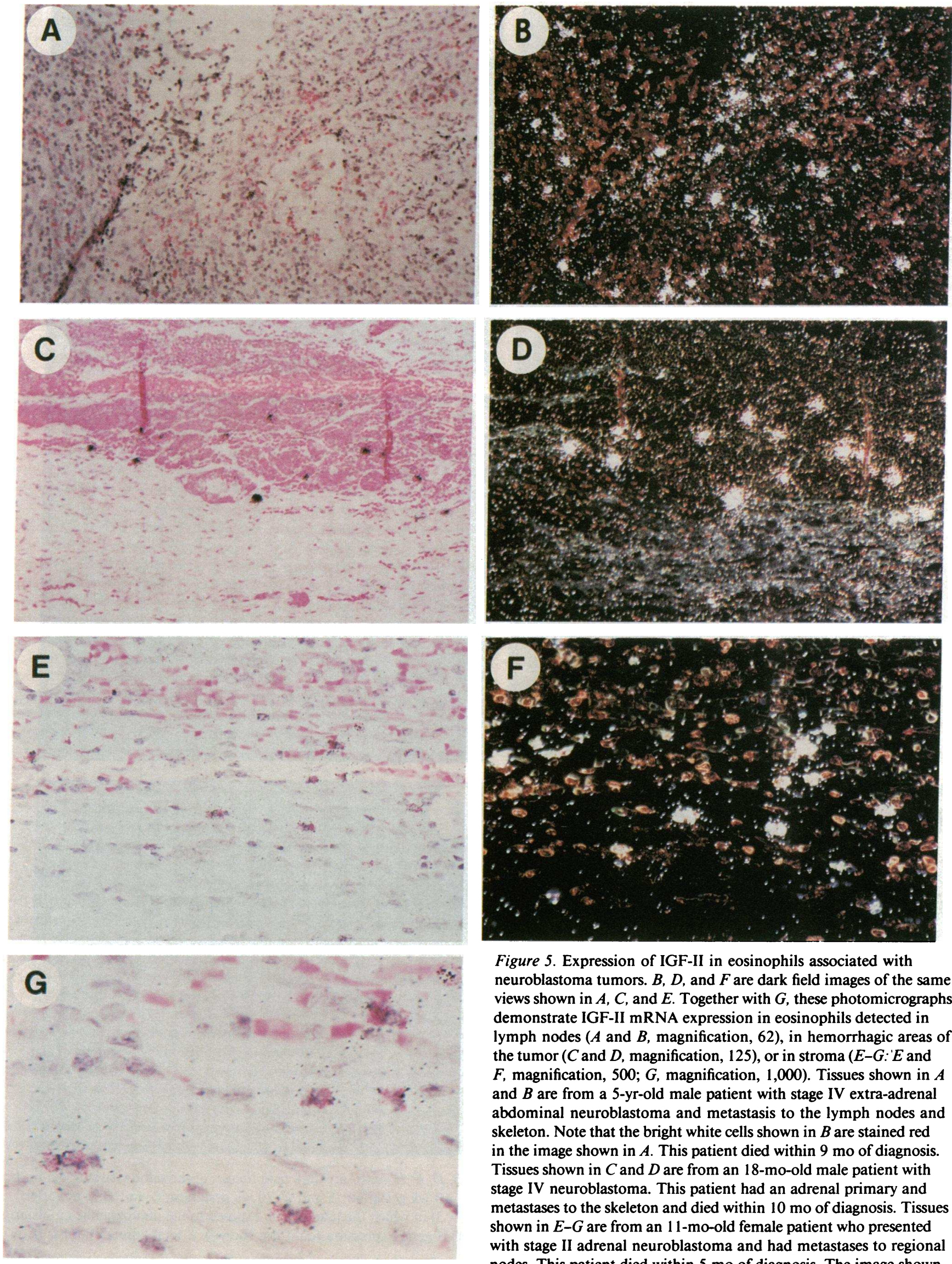

Figure 5. Expression of IGF-II in eosinophils associated with neuroblastoma tumors. $B, D$, and $F$ are dark field images of the same views shown in $A, C$, and $E$. Together with $G$, these photomicrographs demonstrate IGF-II mRNA expression in eosinophils detected in lymph nodes ( $A$ and $B$, magnification, 62), in hemorrhagic areas of the tumor ( $C$ and $D$, magnification, 125$)$, or in stroma $\left(E-G:^{\prime} E\right.$ and $F$, magnification, 500; $G$, magnification, 1,000 ). Tissues shown in $A$ and $B$ are from a 5-yr-old male patient with stage IV extra-adrenal abdominal neuroblastoma and metastasis to the lymph nodes and skeleton. Note that the bright white cells shown in $B$ are stained red in the image shown in $A$. This patient died within 9 mo of diagnosis. Tissues shown in $C$ and $D$ are from an 18-mo-old male patient with stage IV neuroblastoma. This patient had an adrenal primary and metastases to the skeleton and died within 10 mo of diagnosis. Tissues shown in $E-G$ are from an 11-mo-old female patient who presented with stage II adrenal neuroblastoma and had metastases to regional nodes. This patient died within 5 mo of diagnosis. The image shown in $G$ is to demonstrate the eosinophils we detected and is focused to emphasize the cytologic appearance of these cells. At this magnification $(1,000)$ the silver grains over the cells and the cells themselves do not always appear in the same focal plane. Thus, the number of grains over the cells illustrated in this panel is lower than that actually seen by microscopy (For reference, note the grains over the same cells in $E$ ). 

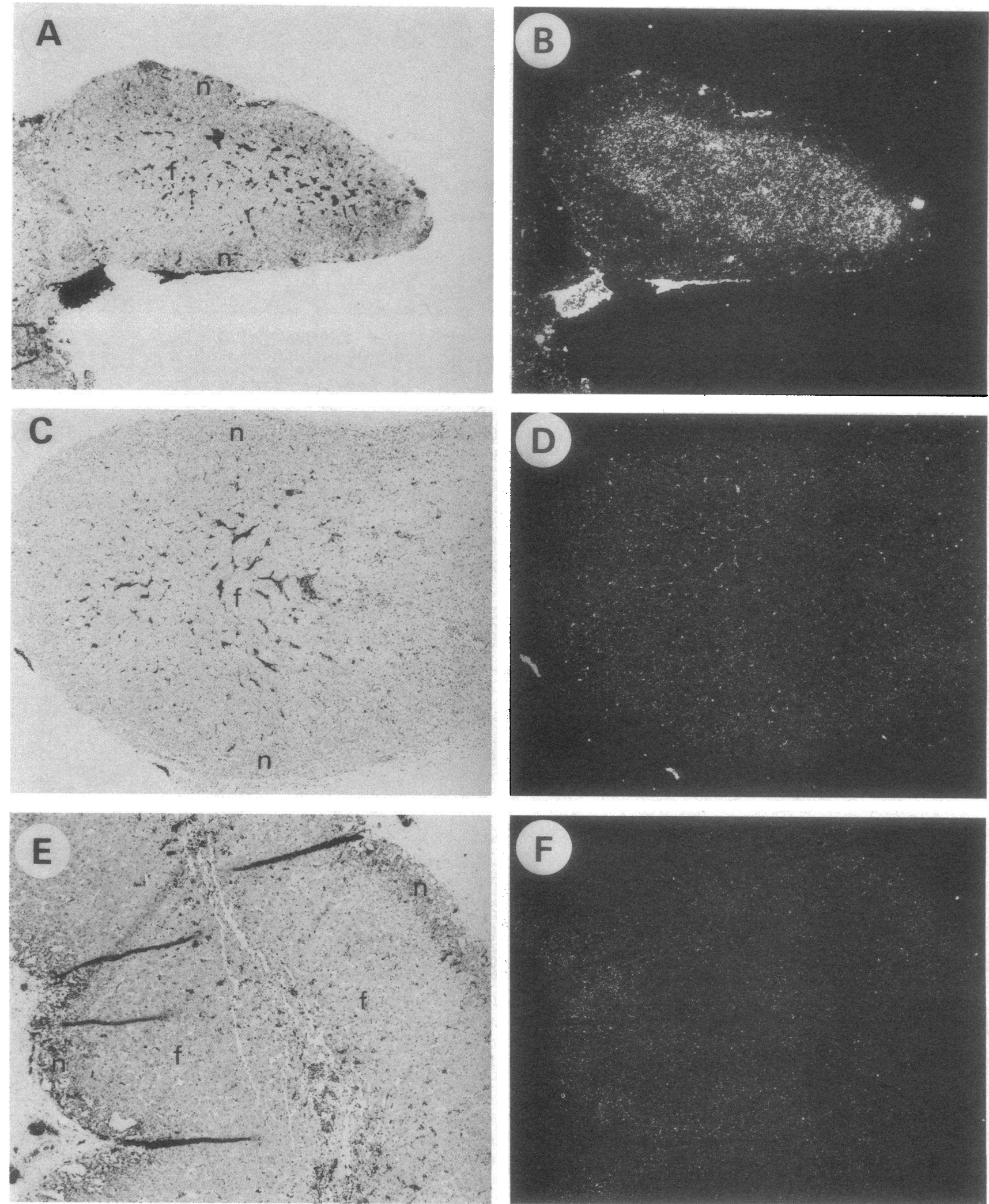

Figure 6. Developmental expression of IGF-II in the human adrenal gland. $B, D, F, H$, and $J$ are dark field images of the same views shown in $A$, $C, E, G$, and $I$ (magnification, 62). $A$ and $B: 7-8$ wk gestation; $C$ and $D: 9-10$ wk gestation; $E$ and $F: 20$ wk gestation; $G$ and $H: 4$ mo after birth; $I$ and $J$ : adult. Images shown are from a representative experiment $(n=3)$ in which the tissues were exposed to the photographic emulsion for $5 \mathrm{~d}$. Longer exposure $(12 \mathrm{~d})$ did not reveal any additional sites of IGF-II gene expression (data not shown). $f$ : fetal adrenal cortex; $n$ : neocortex; $M$ : medulla; $C$ : cortex. 

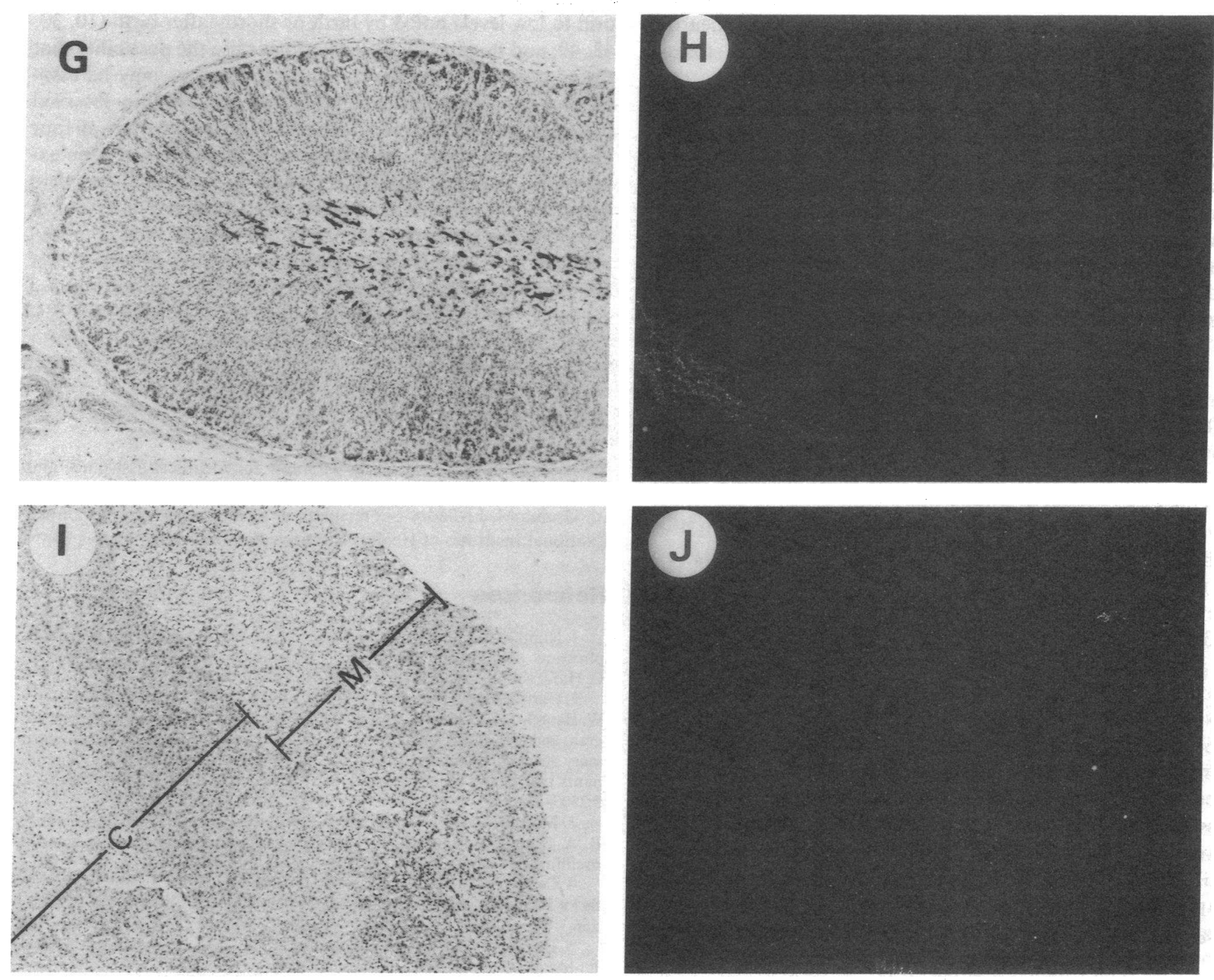

Figure 6 (Continued)

cells during gestation, IGF-II expression was not detected by this technique in cells of the embryonic adrenal medulla (e.g., Fig. 6, $E$ and $F)(23)$ or in adrenal cortical or medullary cells from three children aged 1-11 mo (Fig. 6, $G$ and $H$; and data not shown). Although we have previously detected expression of IGF-II mRNA by Northern blot analysis in adrenal medullary tissue from adults (22), we were unable in repeated studies to detect expression by in situ hybridization (Fig. 6, $I$ and $J$ ).

\section{Discussion}

The proliferation of a human neuroblastoma cell line, SK-NAS, is mediated by endogenously produced IGF-II (22). However, we observed that many neuroblastoma cell lines grow poorly when plated at low density into medium without growth factors. In this study we demonstrate that exogenously added IGF-II stimulates the growth of several human neuroblastoma cell lines in a dose-dependent manner (Fig. 1). Together with our finding that IGF-II is expressed in cells of nonmalignant tissues associated with neuroblastoma tumor cells (Figs. 4 and 5), these data indicate that locally produced IGF-II may stimulate the proliferation of neuroblastoma.
IGF-II-mediated growth of neuroblastoma requires appropriate receptors through which this factor can stimulate cellular proliferation. IGF-II binds with high affinity to at least two receptors: the type I IGF receptor, an IGF sensitive tyrosinespecific protein kinase, and the type II/mannose-6-phosphate receptor $(2,3,32)$. Only the type I receptor has been shown to mediate the mitogenic activities of IGF-II $(4,5)$. Using ${ }^{125}$ IIGF-I, Shigematsu et al. (14) detected type I IGF receptors in cells of both the fetal and adult human adrenal medulla and cortex. We previously reported type I IGF receptor gene expression in both adrenal medullary and cortical tissue and in 8 of 8 human neuroblastoma tumors (22). Cell surface type I IGF receptors have also been demonstrated on SH-SY5Y human neuroblastoma cells $(33,34)$ and in neuroblastomas from rats (35) and mice (36). Moreover, the type I IGF receptors on SK-N-AS neuroblastoma cells bind IGF-II and mediate IGFII-induced $\left[{ }^{3} \mathrm{H}\right]$ thymidine uptake in these cells (22).

Although the proliferation of some neuroblastomas may be mediated by an IGF-II autocrine mechanism (22; and Figs. 2 and 3), our demonstration of IGF-II gene expression in cells of tumor stroma, capsule, adrenal cortical tissues, and tumor infiltrating eosinophils (Figs. 4 and 5) suggests that IGF-II pro- 
duced by nonmalignant cells either within or adjacent to neuroblastoma tumors may function in a paracrine manner to stimulate their proliferation. Particularly noteworthy is the observation of IGF-II gene expression in adrenal cortical tissue adjacent to tumor (Fig. 4), but not in such tissue obtained from patients without adrenal tumors. It will be important to determine whether the synthesis of this growth-stimulatory ligand in nonmalignant tissues associated with neuroblastoma tumor cells is mediated by tumor-derived factors. Other studies demonstrating IGF-II expression in established fibroblast cell lines and in benign and malignant human breast tissue (37) have raised the possibility that locally produced IGFs may also mediate the growth of other human tumors as well (38).

IGF-II gene expression has been detected in both parenchymal and stromal tissue of many different embryonic organs $(10,26,29$; and this study), suggesting that IGF-II may function normally in the human fetus to promote growth. Studies in our laboratory have suggested that neuroblastoma tumor cell lines correspond to adrenal chromaffin cells that are recognizable at different times during development $(23,39)$. IGF-II mRNA and protein is detected in adult adrenal medulla (17, 22) and neuroblastoma cell lines that express markers associated with mature adrenal medullary tissue (Fig. 2, Table I) (23). This finding is compatible with the origin of such tumors in adrenal medullary cells that expressed IGF-II at the time of their malignant transformation. The proliferation of these tumors may not require exogenous sources of IGF-II (e.g., SK-NAS cells [22]). In contrast, neuroblastomas containing tumor cells that do not express IGF-II may be dependent upon exogenous IGF-II, potentially from adjacent stroma or other normal tissues (Figs. 4 and 5). Such tumors may arise from more primitive adrenal medullary cells (Table I), which do not express IGF-II but are surrounded during development by tissues that express very high levels of the gene (Fig. 6). These observations suggest that the growth mechanisms mediating the proliferation of neuroblastoma tumor cells may be the same mechanisms mediating the growth of normal medullary cells during adrenal organogenesis.

A majority of the patients diagnosed with neuroblastoma present with metastases to adjacent lymph nodes, bones, liver, or skin (20). Significantly, all of these tissues express high levels of IGF-II mRNA or protein at the times during development when neuroblastomas are detected in such tissues $(10,26,29$, $30,40,41$, and this study). In contrast, metastatic neuroblastoma is rarely detected in brain and lung, common sites of metastases for other pediatric tumors. These tissues do not express high levels of IGF-II in the human fetus or adult $(10,42$, 43). Observations that IGF-II can function as a chemoattractant $(44,45)$ raise the possibility that neuroblastomas metastasize to specific tissues due to the influence of IGF-II produced by these tissues. Alternatively, neuroblastomas may metastasize to various sites throughout the body and proliferate only in tissues that contain high concentrations of IGF-II. Neuroblastomas in which tumor cells express high levels of IGF-II mRNA, a minority of the tumors examined to date, may survive in other tissues such as lung that express little or no IGF-II.

Neuroblastomas of low clinical stage in children under $1 \mathrm{yr}$ of age and stage IVS disease often regress without cytotoxic therapy $(46,47)$. Such tumors may be detected in the adrenal, liver, and skin (47). IGF-II expression in these tissues has been shown to decline from high levels observed early during gesta- tion to low levels noted by birth or shortly after birth $(10,30$, 48, 49; and this study). These findings raise the possibility that the spontaneous regression of neuroblastomas may be associated with the diminished level of IGF-II expression observed in these tissues at the time of regression. In our analysis, all four of the neuroblastomas in which we detected IGF-II gene expression in adrenal cortical cells adjacent to the tumor were derived from patients aged newborn to $11 \mathrm{mo}$. The tumor in three of these patients, newborn to 2 mo of age, have regressed and these individuals are alive with no evidence of disease after 5-13 yr of follow up. The fourth patient died within 5 mo of diagnosis. In contrast to the tumor tissue from the three patients who survived, tumor tissue from this patient, aged 11 mo, expressed IGF-II.

\section{Acknowledgments}

We would like to thank Carly Rubinow for technical assistance and Rick Dreyfuss for photomicroscopy.

Osama M. El-Badry is a recipient of a National Research Council (National Institutes of Health) Research Associateship.

\section{References}

1. Humbel, R. E. 1984. Insulin-like growth factors, somatomedins, and multiplication stimulating activity. In Hormonal Proteins and Peptides C. H. Li, editor. Academic Press, Inc., New York. Vol. XII. 57-79.

2. Ullrich, A., A. Gray, A. W. Tam, T. Yang-Feng, M. Tsubokawa, C. Collins, W. Henzel, T. Le Non, S. Kathuria, E. Chen, S. Jacobs, U. Franke, J. Ramachandran, and Y. Fujita-Yamaguchi. 1986. Insulin-like growth factor I receptor primary structure: comparison with insulin receptor suggests structural determinants that define functional specificity. EMBO (Eur. Mol. Biol. Organ.) J. 5:2503-2512.

3. Morgan, D. O., J. C. Edman, D. N. Standring, V. A. Fried, M. C. Smith R. A. Roth, and W. J. Rutter. 1987. Insulin-like growth factor II receptor as multifunctional binding protein. Nature (Lond.). 329:301-307.

4. Conover, C. A., R. G. Rosenfeld, and R. L. Hintz. 1987. Insulin-like growth factor II binding and action in human fetal fibroblasts. J. Cell. Physiol. 133:560 566

5. Furlanetto, R. W., J. N. DiCarlo, and C. Wisehart. 1987. The type II insulin-like growth factor receptor does not mediate deoxyribonucleic acid synthesis in human fibroblasts. J. Clin. Endocrinol. Metab. 64:1142-1149.

6. Furlanetto, R. W., L. E. Underwood, J. J. Van Wyk, and A. J. D'Ercole. 1977. Estimation of somatomedin-C levels in normals and patients with pituitary disease by radioimmunoassay. J. Clin. Invest. 60:648-657.

7. Schoenle, E., J. Zapf, R. E. Humbel, and E. R. Froesch. 1982. Insulin-like growth factor I stimulates growth in hypophysectomized rats. Nature (Lond.). 296:252-253.

8. Brown, A. L., E. E. Graham, S. P. Nissley, D. J. Hill, A. J. Strain, and M. M. Rechler. 1986. Developmental regulation of insulin-like growth factor II mRNA in different rat tissues. J. Biol. Chem. 261:13144-13150.

9. Levinovitz, A., and G. Norstedt. 1989. Developmental and steroid hormonal regulation of insulin-like growth factor II expression. Mol. Endocrinol. 3:797-804.

10. Scott, J., J. Cowell, M. E. Robertson, L. M. Priestley, R. Wadey, B. Hopkins, J. Pritchard, G. I. Bell, L. B. Rall, C. F. Graham, and T. J. Knott. 1985. Insulin-like growth factor-II gene expression in Wilms' tumor and embryonic tissues. Nature (Lond.). 317:260-262.

11. van Dijk, J. P., A. K. Tanswell, and J. R. G. Challis. 1988. Insulin-like growth factor (IGF)-II and insulin, but not IGF-I, are mitogenic for fetal rat adrenal cells in vitro. J. Endocrinol. 119:509-516.

12. Froesch, E. R., C. Shmid, J. Schwander, and J. Zapf. 1985. Actions of insulin-like growth factors. Annu. Rev. Physiol. 47:443-467.

13. Sara, V. R., K. Hall, M. Misaki, L. Fryklund, N. Christensen, and L. Wetterberg. 1983. Ontogenesis of somatomedin and insulin receptors in the human fetus. J. Clin. Invest. 71:1084-1094.

14. Shigematsu, K., M. Niwa, M. Kurihara, K. Yamashita, K. Kawai, and H. Tsuchiyama 1989. Receptor autoradiographic localization of insulin-like growth factor-I (IGF-I) binding sites in human fetal and adult adrenal glands. Life Sci. 45:383-389.

15. Pillion, D. J., M. Yang and W. E. Grizzle. 1988. Distribution of receptors for insulin and insulin-like growth factor I (Somatomedin C) in the adrenal gland. Biochem. Biophys. Res. Commun. 154:138-145. 
16. Hoppener, J. W. M., S. Mosselman, P. J. M. Roholl, C. Lambrechts, R. J. C. Slebos, P. de Pagter-Holthuizen, C. J. M. Lips, H. S. Jansz, and J. S Sussenbach. 1988. Expression of insulin-like growth factor-I and -II genes in human smooth muscle tumours. EMBO (Eur. Mol. Biol. Organ.) J. 7:13791385.

17. Haselbacher, G. K., J. C. Irminger, J. Zapf, W. H. Ziegler, and R. E. Humbel. 1987. Insulin-like growth factor II in human adrenal pheochromocytomas and Wilms tumors: expression at the mRNA and protein level. Proc. Natl. Acad. Sci. USA. 84:1104-1106.

18. Tricoli, J. V., L. B. Rall, C. P. Karakousis, L. Herrera, N. J. Petrelli, G. I. Bell, and T. B. Shows. 1986. Enhanced levels of insulin-like growth factor messenger RNA in human colon carcinomas and liposarcomas. Cancer Res. 46:61696173.

19. Cariani, E., C. Lasserre, D. Seurin, B. Hamelin, F. Kemeny, D. Franco, M. P. Szech, A. Ullrich, and C. Brechot. 1988. Differential expression of insulinlike growth factor II mRNA in human primary liver cancers, benign liver tumors, and liver cirrhosis. Cancer Res. 48:6844-6849.

20. Pizzo, P. A., J. S. Miser, J. R. Cassady, and R. M. Filler. 1985. Solid Tumors of childhood. In Cancer: Principles and Practice of Oncology 2. DeVita, Jr. V. T., S. Hellman, and S. A. Rosenberg, editors. J. B. Lippincott Co., Philadelphia. 1511-1574.

21. Israel, M. A. 1986. The evolution of clinical molecular genetics: neuroblastoma as a model tumor. Am. J. Pediatr. Hematol. Oncol. 8:163-172.

22. El-Badry, O. M., J. A. Romanus, L. J. Helman, M. J. Cooper, M. M. Rechler, and M. A. Israel. 1989. Autonomous growth of a human neuroblastoma cell line is mediated by insulin-like growth factor II. $J$. Clin. Invest. 84:829-839.

23. Cooper M. J., G. M. Huchins, P. S. Cohen, L. J. Helman, R. J. Mennie, and M. A. Israel. 1990. Human neuroblastoma tumors correspond to the arrested differentiation of chromaffin adrenal medullary neuroblasts. Cell Growth and Differentiation. 1:149-159.

24. Chirgwin, J. M., A. E. Przybyla, R. J. MacDonald, and W. J. Rutter. 1979. Isolation of biologically active ribonucleic acid from sources enriched in ribonuclease. Biochemistry. 18:5294-5299.

25. Cohen, P. S., R. C. Seeger, T. J. Triche, and M. A. Israel. 1988. Detection of $\mathrm{N}$-myc gene expression in neuroblastoma tumors by in situ hybridization. Am. J. Pathol. 131:391-397.

26. Han, V. K. M., A. J. D'Ercole, and P. K. Lund. 1987. Cellular localization of somatomedin (insulin-like growth factor) messenger RNA in the human fetus. Science (Wash. DC). 236:193-197.

27. Van Wyk, J. J., D. C. Graves, S. J. Casella, and S. Jacobs. 1985. Evidence from monoclonal antibody studies that insulin stimulated deoxyribonucleic acid synthesis through the type I somatomedin receptor. J. Clin. Endocrinol. Metab. 61:639-643.

28. Flier, J. S., P. Usher, and A. C. Moses. 1986. Monoclonal antibody to the type I insulin-like growth factor (IGF-I) receptor blocks IGF-I receptor-mediated DNA synthesis: clarification of the mitogenic mechanisms of IGF-I and insulin in human skin fibroblasts. Proc. Natl. Acad. Sci. USA 83:664-668.

29. Han, V. K. M., P. K. Lund, D. C. Lee, and A. J. D'Ercole. 1988. Expression of somatomedin/insulin-like growth factor messenger ribonucleic acids in the human fetus: identification, characterization, and tissue distribution. Clin. Endocrinol. Metab. 66:422-429.

30. Gray, A., A. W. Tam, T. J. Dull, J. Hayflick, J. Pintar, W. K. Cavenee, A Koufos, and A. Ullrich. 1987. Tissue-specific and developmentally regulated transcription of the insulin-like growth factor 2 gene. DNA (NY). 6:283-295.

31. Reeve, A. E., M. R. Eccles, R. J. Wilkins, G. I. Bell, and L. J. Millow. 1985. Expression of insulin-like growth factor-II transcripts in Wilms' tumour. Nature (Lond.). 317:258-260.
32. Roth, R. A. 1988. Structure of the receptor for insulin-like growth factor II: the puzzle amplified. Science (Wash. DC). 239:1269-1271.

33. Recio-Pinto, E., and D. N. Ishii. 1988. Insulin and insulinlike growth factor receptors regulating neurite formation in cultured human neuroblastoma cells. J. Neurosci. Res. 19:312-320.

34. Ota, A., G. L. Wilson, O. Spilberg, R. Pruss, and D. Leroith. 1988. Functional insulin-like growth factor I (IGF-I) receptors are expressed by neural derived continuous cell lines. Endocrinology. 122:145-152.

35. Sturm, M. A., C. A. Conover, H. Pham, and R. G. Rosenfeld. 1989. Insulin-like growth factor receptors and binding protein in rat neuroblastoma cells. Endocrinology. 124:388-396.

36. Ota, A., G. L. Wilson, and D. Leroith. 1988. Insulin-like growth factor I receptors on mouse neuroblastoma cells: two $B$ subunits are derived from differences in glycosylation. Eur. J. Biochem. 174:521-530.

37. Yee, D., K. J. Cullen, S. Paik, J. F. Perdue, B. Hampton, A. Schwartz, M. E. Lippman, and N. Rosen. 1988. Insulin-like growth factor II mRNA expression in human breast cancer. Cancer Res. 48:6691-6696.

38. Yee, D., S. Paik, G. S. Lebovic, R. R. Marcus, R. E. Favoni, K. J. Cullen, M. E. Lippman, and N. Rosen. 1989. Analysis of insulin-like growth factor I gene expression in malignancy: evidence for a paracrine role in human breast cancer. Mol. Endocrinol. 3:509-517.

39. Thiele, C. J., C. McKeon, T. J. Triche, R. A. Ross, C. P. Reynolds, and M. A. Israel. 1987. Differential protooncogene expression characterizes histopathologically indistinguishable tumors of the peripheral nervous system. J. Clin. Invest. 80:804-811.

40. Mohan, S., J. C. Jennings, T. A. Linkhart, and D. J. Baylink, 1988. Primary structure of human skeletal growth factor: homology with human insulin like growth factor-II. Biochim. Biophys. Acta. 966:44-55.

41. Frolik, C. A. L. F. Ellis, and D. C. Williams. 1988. Isolation and characterization of insulin-like growth factor-II from human bone. Biochem. Biophys. Res. Commun. 151:1011-1018.

42. Sandberg, A.-C., C. Engberg, M. Lake, H. von Hol, and V. R. Sara. 1988 The expression of insulin-like growth factor I and insulin-like growth factor II genes in the human fetal and adult brain and in glioma. Neurosci. Lett. 93:114 119.

43. Haselbacher, G. K., M. E. Schwab, A. Pasi, and R. E. Humbel. 1985 Insulin-like growth factor II (IGF-II) in human fetal brain: regional distribution of IGF-II and of higher molecular mass forms. Proc. Natl. Acad. Sci. USA. 82:2153-2157.

44. Stracke, M. L., J. D. Engel, L. W. Wilson, M. M. Rechler, L. A. Liotta, and E. Schiffman. 1989. The type I IGF receptor is a motility receptor in human melanoma cells. J. Biol. Chem. 264:21544-21549.

45. El-Badry, O. M., C. Minniti, E. C. Kohn, P. J. Houghton, W. H. Daughaday, and L. J. Helman. 1990. Insulin like growth factor II acts as an autocrine growth and motility factor in human rhabdomyosarcoma tumors. Cell Growth and Differentiation. 1:325-331.

46. Everson, T. C., and W. H. Cole. 1966. Spontaneous regression of cancer. W. B. Saunders, Philadelphia. 11-87.

47. Evans, A. E., J. Gerson, and L. Schnaufer. 1976. Spontaneous regression of neuroblastoma. Natl. Cancer Inst. Monogr. 44:49-54.

48. Voutilainen, R., and W. L. Miller. 1988. Developmental and hormonal regulation of $m R$ NAs for insulin-like growth factor II and steroidogenic enzymes in human fetal adrenals and gonads. DNA. 7:9-15.

49. Brice, A. L., J. E. Cheetham, V. N. Bolton, N. C. W. Hill, and P. N. Schofield. 1989. Temporal changes in the expression of the insulin-like growth factor II gene associated with tissue maturation in the human fetus. Development. 106:543-554. 